\title{
The Quest to Reclaim the Lost Status of Hijras in India: A Reading of Living Smile Vidya's I Am Vidya: A Transgender's Journey and A. Revathi's The Truth About Me: A Hijra Life Story
}

\author{
Pratishi Hazarika
}

\begin{abstract}
In precolonial India, a culture of gender and sexual fluidity flourished in society, attributing dignified positions to hijras. However, with the arrival of the British colonial rulers the hijra community became marginalized through laws such as Section 377 of the Indian Penal Code of 1861 and the Criminal Tribes Act of 1871. In contemporary India, the echoes of the colonial regulation of hijras remain prevalent. This paper aims to interrogate the systems of domination within the terrains of gender and sexuality that leads to the subordination of the hijra community. It shall also examine the systematic and systemic disempowerment of hijras and their elimination from the narratives of the nation, as depicted in the transgender autobiographies, I Am Vidya: A Transgender's Journey (2007) by Living Smile Vidyaand The Truth About Me: A Hijra Life Story (2010) by A. Revathi. In the former text, the experience of oppression of the writer for her Dalit identity and her victimization by the postcolonial ideology of gender conformity and heteronormativity, shall be analyzed. Further, in A. Revathi's autobiography, the writer's traumatic experiences and the lack of legal rights for the hijra community would be discussed. These autobiographies contribute to the identity politics of transgender individuals in postcolonial India, as the writers strive to abolish stereotypes and demand for their right to freedom and equality. The methodology of close reading shall be combined with the postcolonial and feminist approach, to conduct the study.
\end{abstract}

Keywords: Postcolonial India, Hijra Identity, Masculinity, Transgender Autobiographies, Transgender Rights.

\section{Introduction}

This section should be concise and define the background and significance of the research by considering the relevant literature, particularly the most recent publications. When preparing the introduction, please bear in mind that some readers will not be experts in your research field.

In India, the term "hijra" refers to a person born biologically male, with a feminine gender expression that situates them in a liminal position identified as the "third gender" in society. Serena Nanda in the seminal text, Neither Man nor Woman: The Hijras of India (1990), defines "hijras", "as an alternative gender, neither men nor women" (p. 13). Nanda mentions that the most commonly used English translations of the term "hijra" in India, is either "eunuch" or "hermaphrodite" (intersexed), terms that imply "impotence" which is a deformity of the male genitalia (p. 13). Nanda claims that the factor of impotence is central to "the definition of hijra as not man" (p. 14). Another seminal figure Jessica Hinchy in the text, 
Governing Gender and Sexuality in Colonial India: The Hijra, c. 1850-1900 (2019), states that the term "hijra" originated from "an Urdu word derived from Persian, probably either from hiz, the Persian root word meaning 'effeminate', or hich, a person who ishichgah or nowhere" (p. 19).

The existence of hijras (also known as "tirunangai", "kinnar", “aravani”, "kothi”, "jogappas" etc.), dates back to the Vedic period when they were revered and accepted in the Indian culture. The concept of "tritiya prakriti" (meaning, "third nature" or "third sex") and "napumsaka" (meaning, "impotent") was acknowledged in the Hindu epics, mythological texts, folk tales and the early Vedic and Puranic literature. Vinay Lal in the essay, "Not This, Not That: The Hijras of India and the Cultural Politics of Sexuality" (1999), discusses the popular myths associated with hijras, to provide religious sanction to their community. Lal mentions that hijras often identify with the figure of Lord Shiva as "Ardhanarishvara" (meaning, "the Lord who is half woman") (pp. 124-125), conceived from the amalgamation of the deities, Lord Shiva and Parvati. Hijras also relate with the "Mohini" avatar ("female form") of Lord Vishnu (Nanda, 1999, p. 20).

The Hindu epic, Mahabharata mentions characters practicing androgyny, gender fluidity and cross-dressing, such as the figure of Arjuna who is disguised as a eunuch teacher named Brihannala in the court of King Virata (Lal, 1999, pp. 125-126). Even, Shikhandi is reborn as a man and confronts Bhishma in the Kurukshetra war and Lord Krishna transforms into a woman and marries Arjuna's son Lord Aravan. Myths about the existence of transgender people are also included in the Hindu epic, Ramayana. Some of these myths are mentioned in the autobiographies by the transgender writers to be discussed in this paper. The allusion to these mythical tales validates the existence of transgender individuals since the ancient times. The texts also juxtapose the traditional stature attributed to the hijra community and their descent in the modern times.

Even during the Mughal period, hijras occupied dignified positions as confidantes, advisors, and harem guards in the royal court (Konduru\&Hangsing, 2018, p. 12). They also performed the ritual of "badhai" (meaning, blessings) during child births and weddings, since hijras were viewed as agents of fertility. So, in precolonial India, hijras were an integral part of the social landscape. However, their condition deteriorated with the arrival of the British colonial rulers who forced their ideologies about gender binary and heteronormativity upon the subjects.In the nineteenth century, the colonial government in India anticipated a manageable and law- abiding colonized population that demanded the regulation of gender expression and sexuality of the subjects. Consequently, hijras became criminalized in society through the enforcement of laws such as Section 377 of the Indian Penal Code (IPC) of 1861 and the Criminal Tribes Act (CTA) of 1871 (Hinchy, 2019, pp. 2-3). Section 377 prohibited consensual sexual acts between adults belonging to the same sex and the Criminal Tribes Act targeted various ethnic communities and social groups that were regarded as hereditary offenders due to their primary occupation. These laws impacted the status of various gender non-conforming people and their communities as they were designated as criminals, due to their bodies, gender performances, sexual practices and public activities like singing and dancing. Hijras were also looted from the beneficiaries and land granted to them by the Indian kings, and denied civil rights. This caused a change of perspective towards the hijra community as they began to be ridiculed, harassed and exploited in society.

In present-day India, the echoes of the colonial regulation of hijras remain prevalent. On one hand, they are established as auspicious beings within the Indian social system and on the other hand, distinguished for their deviations. Due to their transgression of the gender binary, hijras are criminalized and denied education, shelter, employment, healthcare facilities and other legal rights that lead to their marginalized position in society. Their victimization ranges from minor forms of harassment and bullying to blatant physical, sexual and verbal abuse that leads to their psychological trauma. The stigma associated with being a 
The Quest to Reclaim the Lost Status of Hijras in India: A Reading of Living Smile Vidya's I Am Vidya: A Transgender's Journey and A. Revathi's The Truth About Me: A Hijra Life Story

hijra makes them an outsider both within their families and in the society.

The traumatic experiences undergone by the hijra community in society necessitate the production of literature from the margins that represent their lived realities. Such form of writing becomes political due to the quest for agency, equality and empowerment, initiated by the authors who represent the marginalized community. This explains the significance of the selected autobiographies titled, I Am Vidya: A Transgender's Journey (2007) by Living Smile Vidya and The Truth About Me: A Hijra Life Story (2010) by A. Revathi, which are considered to be the first transgender autobiographies of India. This study, through an analysis of the selected autobiographies, aims to interrogate the systems of domination within the terrains of gender and sexuality that subordinates the hijra community, and justifies the violence (physical/mental) against them. It shall also examine the systematic and systemic disempowerment of hijras and their elimination from the narratives of the nation, as depicted in the selected texts. These autobiographies contribute to the identity politics of transgender individuals in postcolonial India, as the writers strive to abolish stereotypes and demand for their right to freedom and equality. The methodology of close reading shall be combined with the postcolonial and feminist approach, to conduct the study. The significance of this paper is marked by the absence of a comprehensive literary study in the specified area, conducted through a postcolonial and feminist lens.

\section{Textual Analysis and Discussion of Living Smile Vidya's I Am Vidya: A Transgender's Journey and A. Revathi's The Truth About Me: A Hijra Life Story}

Living Smile Vidya's autobiography titled, I Am Vidya: A Transgender's Journey, presents the traumatic experiences and struggles of the writer as a "tirunangai" (Tamil word for a transgender person who transitions from male to female). Vidya was born in Tamil Nadu in 1982, as a male child, named Saravanan, after years of devotion to deity Murugan, to her parents who desired for a son, after having a stillborn boy child and four daughters. For Vidya, the experience of oppression was double layered due to her Dalit and transgender identity. Her father considered his so-called son, as the only hope that shall alleviate their plight and struggle for survival. He expected Saravanan to excel in his academic performance and to become a district collector; and inflicted severe corporeal punishment upon him during his failures. Vidya narrates,

My father's life was one of frustration-frustration that his lack of formal education beyond Class 8 had landed him in a lowly sweeper's job...He constantly dreamed of his son growing up to be a district collector-surely the top job in India! His dreams, desires and ambitions all centred on his son of the future. (p. 11)

The father's eagerness to have a male child coupled with the view that the son is responsible for the economic progress of the family reflects the patriarchal mindset of the society. Vidya's non-normative gender identity and performance brings disgrace to her family, particularly to her father who physically assaults her in an attempt to instill the sense of idealized masculine performance upon his son.

Apart from her family, Vidya is subjected to violence (physical/mental) and bullying at school and public places. She narrates,

Even kids didn't spare me. Once they followed me when I was on field duty and sang raucous film songs at me. Who taught them to do this? Where did they learn such domineering behavior? If you see a tirunangai, attack her, insult her, make her cry; 
chase her away whimpering, screaming- that seemed to be the rule, regardless of race, religion or creed. (p. 135)

These experiences impact her psyche making her reflect on her unconventional desires and identity. She questions, "What's wrong with my preferences? Why do people find something odd in what comes to me naturally?" (p. 22). Vidya is victimized by the postcolonial ideology of gender conformity and heteronormativity that ultimately compels her to flee from her family, in search of her authentic self.

In order to establish her female identity, Vidya sacrifices her desire to complete her $\mathrm{PhD}$ and her passion for theatre, and associates herself with the hijra community. With no financial support, she engages in the practice of begging to collect money for her "Nirvana" (meaning, emasculation surgery). Nirvana is a crucial ceremony for transgender individuals that grants them "badhai" rights, the custom in which they sing, dance and bestow blessings during marriages and childbirths, a power believed to have been granted to them by Lord Rama. In Neither Man nor Woman: The Hijras of India, Nanda describes the ritual as,

Emasculation is explicitly a rite of passage, moving the "nirvana" (the one who is operated on) from the status of an ordinary, impotent male to that of a hijra. Through the operation, the former, impotent male person dies, and a new person, endowed with sacred power (shakti), is reborn. (p. 26)

The Nirvana ordeal with its symbolic implications transforms a transgender person into a potentially powerful figure. However, the operation is conducted under unhygienic and fatal conditions. In Vidya's autobiography, the writer narrates her personal experience of undergoing the surgery, conducted in dangerous circumstances, in the absence of trained medical professionals and hospitals. When Vidya along with another hijra named Satya, arrived at the nursing home for their Nirvana, she was horrified to witness the brutality of the procedure. Vidya recounts, "Neither attendant looked like a nurse or a hospital worker. You'd think they belonged to some completely unrelated profession" (p. 6). The text highlights the distinction between the sex reassignment surgery conducted in countries that provide legal recognition to transgender persons and the Nirvana operation carried out in India, devoid of government approval. Vidya compares the operation theatre to "a slaughterhouse" (p. 7) and the ritual is described as an act of butchering of the male genitalia. The patients scribbled their female names on the walls of the hospital room allotted to transgender people, fearing their death during the surgery. Vidya observed that the patients were only subjected to HIV tests which the writer realized was only a means to financially exploit them. This projects the discrimination against hijras in healthcare settings and their exclusion from the purview of legal rights in the country.

Vidya was willing to undertake the risk of going for the surgery to experience the pleasure of being reborn as a woman. Since a child, Vidya had imagined herself to be a woman and she fulfilled her inner longing through the act of cross-dressing. She recalls, "I was aided and abetted by my sister Manju's skirts and midis, her eyeshadow, bangles, bindis and costume jewels." (p. 19). Her longing was so intense that even at the time of her mother's death, Vidya sneaked into a room, "put on one of Manju's skirts, shut the door and started to dance" (p. 21). As a child, Vidya expressed her true identity and innate desires in secrecy, to safeguard the honor of her family. Hence, after associating herself with the hijra community, when she receives the opportunity of undergoing the surgery, she considers it to be a blessing. It is primarily her instinct to live as a woman that makes her endure the pain during the surgery. She states, 
The Quest to Reclaim the Lost Status of Hijras in India: A Reading of Living Smile Vidya's I Am Vidya: A Transgender's Journey and A. Revathi's The Truth About Me: A Hijra Life Story

As the operation reached its climax, the pain rose to unbearable heights - as if someone was digging deep into my innards with a long rod and removing my intestines. Yes, what I saw in that instant was death. They had removed the part of me over which I had shed silent tears of rejection from as far back as I could remembermy penis and my testicles had been excised. (p. 7)

Vidya's suffering subsides after metamorphosing into a woman by discarding her male genitalia, during the Nirvana ordeal. Her sex being reconstructed through the means of a surgery indicates that it is not biological. Moreover, the absence of the uterus and the womb in Vidya makes her a queer and an unconventional woman. Her anatomy does not align with the gender identity claimed by her which is a prerequisite in a patriarchal society. So, the existence of trans women like Vidya, reveals the flaws of the gender binary imposed by society that eliminates alternative identities.

Due to her transgender identity, Vidya was unable to attain a respectable job. The economic status of the hijra community remains precarious as they are excluded from the regular workforce, compelling them to rely on their incomes from begging, extortion and sex work. This in turn amplifies the violence against their community. Vidya states,

As long as I did not want to be a sex worker, begging was my only option. All tirunangais had to face this cold truth. I prepared myself, and put my MA in linguistics into cold storage. (p. 82)

Vidya's decision to not indulge in sex work was the outcome of her privilege of being educated, which enabled her to assert her choice. Unlike Vidya, many hijras are uneducated and hence fail to qualify for jobs leaving them with no other option other than engaging in prostitution, as a means for their survival. This in turn puts them at a higher risk of contracting diseases like AIDS or HIV. However, this claim is by no means an attempt to disqualify Vidya's status as marginalized. She has endured enormous suffering starting from her childhood on account of her lower caste and transgender identity.

Prior to Vidya's transition the only place where she could be her true self was at an NGO introduced by her friend Senthal, who was a closeted transgender person himself. The writer recounts her experience of visiting the NGO for transgender people for the first time, in an aptly titled chapter, "A different world" (p. 40). It symbolized a liberating and safe space for Vidya to articulate her authentic identity. The writer experiences a sense of affinity and kinship, interacting with other transgender people at the NGO that was more accepting of alternative gender and sexual identities. It represented an alternative space for Vidya to explore and assert her true self. The inmates at the NGO advised Vidya against flaunting her feminine traits and to continue living as man, to avoid the tragic fate of transgender individuals in society. However, Vidya was adamant not to succumb to the societal pressure of conforming to the patriarchal and heteronormative ideals. Eventually, Vidya discards her male garb and sets on a quest for her personal freedom and continues her fight for the rights of the transgender community.

Vidya's autobiography, through a detailed account of the writer's subjective experiences, critiques the surveillance of gender non-conforming individuals in a heteropatriarchal society. The text asserts the need for the economic freedom of the transgender community since they are deprived of the right to engage in any economic activity. The writer after navigating through the difficult path of finding a job realizes that the only organizations that were willing to employ transgender people were the NGOs working for 
sexual minorities. However, Vidya was disillusioned with such organizations since they only focus on issues of AIDS or HIV and not the economic freedom of the transgender community. She argues,

No Indian NGO had fought to liberate tirunangais from begging and sex work. What kind of rehabilitation was it to tell them, 'Go on being sex workers, but do it safely?'. (p. 123)

Transgender people are excluded from the mainstream economy and they lack any form of social security. Vidya through her text, demands for change in the perspectives of the state and the general public towards the transgender community, to enable their access to education, employment and healthcare facilities.

As mentioned by Vidya, following a long struggle in the search of an occupation, she was eventually employed as an EDP assistant in a private bank that offered loans to impoverished people. While working with the bank in their Madurai branch, Vidya was encouraged by some of her literary friends to write about her experiences as a transgender person. Her first literary work narrated her experience in Pune which was published in a local magazine named Mozhi. This event served as a turning point in her life as she began to chronicle her lived experiences in her writing. Moreover, Vidya also operated a personal blog, to discuss issues concerning the transgender community. Her works made a significant impact on the readers due to the first-person account of the sufferings of transgender individuals in society. Vidya mentions being approached by a women's magazine that wanted to publish an article on her. She states, "I was not overly enthused by magazine articles on me, but I was happy that a women's magazine was interested in me as a woman. It was an acknowledgment of my womanhood" (p. 131). This confession made by the writer indicates her desire to be recognized as a woman in society. Vidya recounts her struggle to officially change her sex and name in her documents, after her Nirvana operation, as the procedure was not legally sanctioned during her time. This experience coupled with numerous other hurdles encountered by the writer to establish her identity contributed to her ongoing activism in support of the transgender community. Vidya, through her autobiography condemns the systemic disenfranchisement of transgender individuals in the nation and demands for their inclusion within society.

A similar account of gender oppression and gender violence inflicted upon the hijra community is presented by A. Revathi in her autobiography titled, The Truth About Me: A Hijra Life Story. Written from a marginalized position, the text articulates the multilayered process of oppression executed through the factors of economic, sartorial and other forms of domination experienced by the writer due to her "non-normative" gender identity. Born physiologically male in the 1980s in Tamil Nadu, the writer named as Doraisamy, was expected to perform the idealized gender roles prescribed to men in a hetero-patriarchal society. The transgression of the standardized gender norms by the writer made her a victim of gender violence, inflicted by her family and the society. Insults such as "female thing", "female boy" (p. 4) etc. were part of her everyday reality. She deliberates,

...why God had chosen to inflict this peculiar torture on me, and why He could not have created me wholly male or wholly female. Why am I a flawed being... (p. 15)

The text projects the dilemma of transgender individuals who are categorized as abnormal and deviant in society. By recounting her personal experiences of being traumatized and exploited as a trans woman and a member of the hijra community, Revathi attempts to alter perspectives towards her community and highlight the need for transgender 
The Quest to Reclaim the Lost Status of Hijras in India: A Reading of Living Smile Vidya's I Am Vidya: A Transgender's Journey and A. Revathi's The Truth About Me: A Hijra Life Story

rights.

From a tender age, Revathi expressed a fondness for clothing, accessories and traits associated with the female sex. She fulfilled her desire to appear feminine through the act of cross dressing which became a cause of concern for her family. The writer became an anomaly and experienced severe physical and verbal abuse at home and her school, for deviating from the stereotypical gender roles assigned to men. The efforts made to repress her gender expression and sexuality,elucidates the regulatory strategies employed by society to produce disciplined bodies. Such forms of surveillance legitimize the criminalization and subordination of "non-normative" identities, as represented by Revathi in her autobiography.

Unlike Living Smile Vidya who was academically qualified, Revathi on the other hand, dropped out of school in her tenth grade, unable to endure the bullying and humiliation inflicted upon her. During one of her school trips, Revathi met a group of people belonging to the kothi community and experienced a sense of affinity, which influenced her decision to flee to Delhi with them, to explore her gender and sexual identity. In Delhi, the writer associated herself with the hijra community and later underwent the sex change operation to be formally admitted into a hijra family.

By undergoing the surgery, Revathi fulfilled her desire to become a woman but she remained vulnerable to the exploitation of the hijra community by society. In the absence of familial support, education and economic independence, Revathi was compelled to engage in begging and sex work for her survival, making her vulnerable to physical, verbal and sexual abuse. She decided to move to Bengaluru in search of work and became associated with the NGO Sangama that worked for the welfare of sexual minorities. She participated in the activist meetings organized by the NGO that informed her about the importance of transgender rights, essential for the development of their status in society. Currently, Revathi is a writer and a social activist fighting for the rights of transgender individuals and the hijra community.

A. Revathi in the article, "Writing a Life Between Gender Lines: Conversations with A. Revathi about her Autobiography The Truth About Me: A Hijra Life Story"(2014) by Gayathri Prabhu, claims, "...I write. Writing is Activism. I see no difference between the two" (p. 5). The act of narrating the experiences, miseries and struggles, endured by the writer as a transgender person and a member of the hijra community, becomes integral to her healing process. Through her autobiography, Revathi denounces the efforts made by society to dominate and discipline gender non-conforming performances and identities in society.

\section{Conclusion}

Living Smile Vidya and A. Revathi through their autobiographies, question the binary categorization of sex, gender and sexuality in the modern world. The autobiographies highlight the trials and tribulations of the hijra community that particularly resulted as an impact of colonial modernity. The writers critique the strategies implemented by the various societal institutions such as the family, school, economy, government etc. to maintain the established order. It is due to the transgression of the hegemonic ideals of masculinity, femininity and heterosexuality that transgender individuals are relegated to the margins in society. Due to their marginalized position, the hijra community is subjected to violence, humiliation and discrimination in their everyday life.

In present day India, there appears a shift in the status of hijras, manifesting both 
continuities and divergences from the period of colonial policing of gender variant people. Brinda Bose in the text, The Audacity of Pleasure: Sexualities, Literature and Cinema in India (2017), states that "...the evolving relationship of the state with the hijra possess the potential of creating a space for her within it that recognizes her sexual identity without stigmatizing it, and her sexual difference without fetishizing it in a reductive exercise." ( $p$. 135). Bose refers to the attempts made by the state in the recent times to acknowledge hijras and their entitlement to legal rights as citizens. However, this proves to be a difficult task due to the tendency of the state to suppress and purify "non-normative" identities.

In April 15, 2014, the Supreme Court of India granted official recognition to hijras as "third gender", to be situated under the OBC category of reservations in educational institutions and workplaces. At one level, this verdict was lauded for its progressive approach to gender identity. The judgement by providing reservation to hijras under the OBC category would improve employment opportunities for their community, if it is rightfully exercised by the potential workplaces. However, objections against the court judgement were raised by the members of the larger transgender community that includes trans men and trans women who do not identify as hijra, as they feared being clubbed under the umbrella of "third gender". Moreover, the court did not specify on what basis, the government shall identify hijras, making the process liable to misuse. Further, the Supreme Court judgement erased the caste privileges of savarna (upper caste) hijras which was objected by the Dalit (lower caste) hijras (Bose, 2017, pp. 132-133). Living Smile Vidya in an interview posted on the website Sanhati, argues, "Putting transgenders under an oppressed caste category erases the caste privileges that savarna transgenders have. It is better for us to have caste and gender-based reservation so that Dalit women and Dalit transgenders get representation" (Karthik \& Suleiman, 2013). The challenges to the judgement from within the transgender community signify their rising awareness regarding the fundamental rights and privileges that are denied to them.

There was a similar response from the gender non-conforming communities following the verdict of the Supreme Court of India to abolish Section 377 of the Indian Penal Code on 6 September, 2018. Although this decision ensured the decriminalization of the nonheteronormative people, it is regarded as only the beginning of a long road of struggle for civil rights, adoption rights, and other privileges that are still denied to them (Saikia, 2018). Further, the Transgender Persons (Protection of Rights) Act passed by the Parliament on November 26, 2019, providing the right to education, employment, housing etc. was criticized by the transgender community on several grounds, primarily for the decision that the identity of a transgender person is to be certified by the District Magistrate, after producing the proof of sex reassignment surgery (Banerjie, 2019).

Hence in the contemporary times, India has witnessed a gradual change in the perspective towards the hijra community. However, the challenges to the various laws and judgements made in the recent times from within the transgender community reveal the gaps underlying the implementations by the state. It suggests that the battle against the ostracization of the transgender community from the state and other institutions shall continue until they are granted with the legal rights, liberties and privileges offered to the gender conforming and heterosexual subjects.

\section{References}


The Quest to Reclaim the Lost Status of Hijras in India: A Reading of Living Smile Vidya's I Am Vidya: A Transgender's Journey and A. Revathi's The Truth About Me: A Hijra Life Story

Banerjie, A. (2019, November 26). "Why India's transgender people are protesting against a Bill that claims to protect their rights." Scroll.in.

https://scroll.in/article/944882/why-indias-transgender-people-are-protesting-againsta-bill-that-claims-to-protect-their-rights

Bose, B. (2017). The Audacity of Pleasure: Sexualities, Literature and Cinema in India. Three Essays Collective.

Hinchy, J. (2019). Governing Gender and Sexuality in Colonial India: The Hijra, c.18501900. Cambridge University Press.

Karthik, K., \& Suleiman, G. A. (2013, January 26). (Trans)gender and caste lived experience - Transphobia as a form of Brahminism: An Interview of Living Smile Vidya. Sanhati. http://sanhati.com/excerpted/6051/

Konduru, D., \&Hangsing, C. (2018). "Socio-Cultural Exclusion and Inclusion of Transgenders in India."International Journal of Social Sciences and Management,5(1), 1017. http://doi:10.3126/ijssm.v5i1.18147

Lal, V. (1999). Not This, Not That: The Hijras of India and the Cultural Politics of Sexuality. Social Text, 61, 119-140. http://www.jstor.org/stable/488683

Nanda, S. (1999). Neither Man nor Woman:The Hijras of India (2 ${ }^{\text {nd }}$ ed.). Wadsworth Publishing Company.

Prabhu, G. (2014). "Writing a Life Between Gender Lines: Conversations with A. Revathi about her Autobiography".The Truth About Me: A Hijra Life Story. Writers in Conversation, Vol. 1 no. 1, 1-7.

https://dspace.flinders.edu.au/xmlui/bitstream/handle/2328/27270/Revathi_Prabhu.pdf ?sequence $=1 \&$ is Allowed $=\mathrm{y}$

Revathi, A. (2010). The Truth About Me: A Hijra Life Story. (V. Geetha, trans.). Penguin India.

Saikia, N. (2018, September 7). Section 377: Decriminalising homosexuality is great, but the fight for true equality is not yet over. Scroll.in. https://scroll.in/article/893478/section-377-decriminalising-homosexuality-is-greatbut-the-fight-for-true-equality-is-not-over-yet 
Vidya, L. S. (2013). I Am Vidya: A Transgender's Journey. Rupa Publications India.

\section{Bio-note}

Pratishi Hazarika is currently a Ph.D. scholar in the Department of English at Tezpur University, Assam. Her discipline of study is English Literature and the title of her working thesis is A Study of Queer Sexualities and "Non-Normative" Desires in American Contemporary Young Adult Fiction. Her research interest is in the areas of Gender and Sexuality Studies, Queer Theory, Queer Studies and Young Adult Literature. She has pursued her Bachelor of Arts Degree (English Honours) and Master's Degree in English Literature from the University of Delhi. Her postal address is H. No-26, Abhigna Enclave, Jurani Path, Rukminigaon, Khanapara, Assam, Pin Code- 781022.

Email: pratishihazarika@gmail.com 